\title{
PENDEKATAN BEHAVIOR TERHADAP EFIKASI DIRI
}

\author{
Oleh: \\ Nur Hasan \\ Fakultas Tarbiyah IAI Ibrahimy Situbondo \\ nurhasanok46@gmail.com
}

\begin{abstract}
The purpose of this study is to determine the correlation of behavior approach toward self-efficacy. Subjects of this study totaled 35 students. Data collected by behavior approach scale (operant conditioning) and self-efficacy scale. Analisis that used in this research is the statistical data analysis by the number of data pairs of product moment correlation. Based on the analysis turned out the value of $\mathrm{r} x y=0.394$. This number is greater than the significance level of $5 \%=0.334$ to $\mathrm{N}=$ 35. It means significant that the null hypothesis reads "there is no correlation between behavior approach toward self-efficacy of students" (rejected). So there is correlation between behavior approach (operant conditioning) toward self efficacy of students.
\end{abstract}

Key words: Behavior Approach, Self-efficacy

\section{A. Pendahuluan}

Ujian Nasional merupakan salah satu bentuk evaluasi belajar pada akhir tahun pelajaran yang diterapkan pada beberapa mata pelajaran. Ujian Nasional merupakan syarat kelulusan untuk siswa tingkat akhir. Tes yang berperan menentukan lulus atau tidak lulusnya seseorang untuk jenjang pendidikan tertentu berpotensi besar membuat cemas peserta yang mengikutinya. Bayangan buruk seperti tanggapan dari lingkungan sosial, malu dan kehilangan muka memperparah efek kecemasan menghadapi tes tersebut.

Untuk menghadapi bayangan buruk tersebut, saat ini semakin banyak kasus ketidakjujuran dalam pendidikan dikalangan siswa yang sering muncul menyertai aktivitas belajar mengajar, tetapi jarang menjadi pembahasan dalam wacana pendidikan Indonesia.

Perilaku menyontek atau cheating merupakan salah satu fenomena pendidikan yang sering dan bahkan selalu muncul menyertai aktivitas proses belajar mengajar. Perilaku menyontek atau cheating adalah perbuatan yang dilakukan oleh seseorang secara illegal, tidak sah atau curang untuk tujuan yang sah atau terhormat, yang bertujuan 
memperoleh suatu keberhasilan atau menghindari kegagalan dalam menyelesaikan tugas akademik terutama yang berkaitan dengan evaluasi atau ujian hasil belajar. Inilah salah satu indikasi bahwa siswa belum mampu mencapai kemandirian dalam belajar. Siswa yang terbiasa menyontek akan senang menggantungkan pencapaian hasil belajarnya pada orang lain atau sarana tertentu dan bukan pada kemampuan dirinya sendiri.

Dalam sebuah studi menyebutkan bahwa lebih dari 50 persen dan terkadang hingga 80 persen para siswa dilaporkan pernah menyontek ${ }^{1}$. Kurangnya pembahasan mengenai masalah ini dikarenakan orang menganggap kasus ini merupakan hal yang remeh dan wajar, serta tidak berbahaya karena tidak mengandung unsur kekerasan (violence).

Kasus berikutnya adalah kasus penyontekan pada UAN yang dilaksanakan 17 April 2012, Pelaksanaan Ujian Nasional hari kedua di Ponorogo, Jawa Timur, Selasa (17/4) hari itu diwarnai aksi menyontek. Aksi siswa menyontek itu tertangkap kamera Metro TV. Ironisnya pengawas seakan tak melihat aksi nakal para peserta. Pemantauan Metro TV, para siswa rata-rata membawa catatan berupa kertas kecil yang sudah mereka siapkan dari rumah. Namun pengawas tidak melakukan tindakan apapun terhadap para siswa yang diduga menyontek. ${ }^{2}$

Aktivitas tidak adanya kejujuran dalam pendidikan sebenarnya merupakan masalah serius. Tidak jujur dalam pendidikan bertentangan dengan tujuan dari pendidikan nasional. Tujuan pendidikan nasional bukan sekedar membentuk peserta didik yang pintar dengan memperoleh nilai tinggi di setiap mata pelajaran. Namun, seperti dalam UndangUndang RI No. 20 tahun 2003 tentang Sistem Pendidikan Nasional Bab II Pasal 3 bahwa 3, "Pendidikan nasional berfungsi mengembangkan kemampuan dan membentuk watak serta peradaban bangsa yang bermartabat dalam rangka mencerdaskan kehidupan bangsa, bertujuan untuk berkembangnya potensi peserta didik agar menjadi manusia yang beriman dan bertakwa kepada Tuhan Yang Maha Esa, berakhlak mulia, sehat, berilmu, cakap, kreatif, mandiri, dan menjadi warga negara yang demokratis serta bertanggung jawab" .

Realita pendidikan di negeri ini bahwa dalam proses belajar mengajar nampaknya perlu merekonstruksi internal peserta didik, salah satunya ialah dengan melakukan pendekatan yang dapat menumbuhkan

${ }^{1}$ Kompas, Senin, 18 Agustus 2008.

2 Metrotvnews.com

${ }^{3}$ Undang -Undang RI No.20, Sistem Pendidikan Nasional (2003).

116 JURNAL LISAN AL-HAL 
kemandirian dan rasa keberhasilan diri. Pendekatan behavior merupakan salah satu pendekatan yang dapat meningkatkan efikikasi diri siswa., Di dalam teori behavior operant conditioning yaitu dengan pemberian penguatan yang berupa penghargaan, dapat mengurangi kecemasan siswa terhadap Ujian Nasional. Seperti penelitian yang dilakukan oleh Kartika Nur Fathiyah dan Farida Harahap (2008) "Dosen Psikologi Pendidikan dan Bimbingan FIP UNY" dalam penelitiannya mengatakan bahwa pendekatan konseling dapat meningkatkan efikasi diri. ${ }^{4}$

Efikasi memiliki peran yang besar dalam menghadapi masalah supaya kecemasan tidak berlanjut. Efikasi diri dalam belajar adalah penilaian siswa terhadap kemampuan yang dimilikinya dalam mengerjakan tugas sekolah. Siswa dengan efikasi diri tinggi memiliki keyakinan yang besar terhadap kemampuan yang dimilikinya.

Pendekatan Behavior adalah aliran dalam psikologi yang didirikan oleh John B. Watson pada tahun 1913 dan digerakkan oleh Burrhus Frederic Skinner. Behaviorisme lahir sebagai reaksi atas psikoanalisis yang berbicara tentang alam bawah yang tidak tampak. Behaviorisme ingin menganalisis bahwa perilaku yang tampak saja yang dapat diukur, dilukiskan dan diramalkan. Terapi perilaku ini lebih mengkonsentrasikan pada modifikasi tindakan, dan berfokus pada perilaku saat ini daripada masa lampau. Belakangan kaum behavioris lebih dikenal dengan teori belajar, karena menurut mereka, seluruh perilaku manusia adalah hasil belajar. Belajar artinya perubahan perilaku organisme sebagai pengaruh lingkungan. ${ }^{5}$

Proses pembelajaran dapat dilakukan dengan berbagai pendekatan. Salah satu pendekatan yang banyak diterapkan dalam dunia pendidikan adalah pendekatan behavior. Pendekatan behavior dalam pembelajaran merupakan suatu pendekatan yang menekankan pembelajaran melalui aspek-aspek yang dapat dilihat (observable). Penganut filosofi behavioristik percaya bahwa kajian tentang gagasan persepsi atau konsep menurut teoritis kognisi tidak begitu bermanfaat untuk mengubah perilaku, yang penting harus langsung menangani perilaku itu sendiri ${ }^{6}$.

Menurut teori behavior, belajar adalah perubahan tingkah laku sebagai akibat dari interaksi antara stimulus dan respon. Lebih tepatnya,

4 Kartika N., F. \& Farida H, Konseling Sebaya untuk Meningkatan Efikasi Diri Remaja terhadap Perilaku Berisiko, (UNY: 2008).

${ }^{5}$ Rakhmat. Psikologi belajar, (1994), hlm. 21.

${ }^{6}$ WWW.misscounseling.blogspot.com 
belajar adalah perubahan yang dialami siswa dalam hal kemampuannya untuk bertingkah laku dengan cara yang baru sebagai hasil interaksi antara stimulus dan respon. Seseorang dianggap belajar sesuatu setelah bila ia mampu menunjukkan perubahan tingkah laku. Dengan demikian perilaku dikorelasi lingkungan ${ }^{7}$.

Pendekatan behavior memiliki pandangan atau prinsip yang dikembangkan oleh beberapa tokoh behavioral. Hal inilah yang akan dibahas dalam penilitian ini, termasuk bagaimana menggunakan prinsipprinsip tingkah laku tersebut untuk mengubah atau memodifikasi perilaku dan menerapkannya dalam pembelajaran sehingga membantu siswa untuk meningkatkan efikasi diri.

\section{B. Pembahasan}

\section{Operant Conditioning (Pengkondisian Operan)}

Prinsip dasar dari proses belajar yang dianut oleh Thorndike, yaitu dasar dari proses belajar (learning) tidak lain sebenarnya adalah asosiasi. Suatu stimulus (S) akan menimbulkan suatu respons (R) tertentu. Teori ini disebut sebagai teori Stimulus-Respon (S-R). Dalam teori S-R dikatakan bahwa dalam proses belajar, pertama kali organisme (hewan atau orang) belajar dengan cara mencoba-coba (trial and error). Thorndike juga berpendapat bahwa belajar terjadi secara perlahan, bukan secara tibatiba. Dengan kata lain, belajar terjadi secara incremental (bertahap), bukan secara insightful. ${ }^{8}$ Jika organisme berada dalam suatu situasi yang mengandung masalah, maka organisme itu akan mengeluarkan serangkaian tingkah laku dari kumpulan tingkah laku yang ada padanya untuk memecahkan masalah itu. Individu mengasosiasikan suatu masalah tertentu dengan tingkah laku tertentu.

Inti dari pendekatan behavior operant Conditioning yaitu dimana konsekuensi perilaku akan menyebabkan perubahan dalam probabilitas perilaku itu akan terjadi. Konsekuensi-imbalan atau hukuman bersifat sementara (kontingen) pada perilaku organisme.

\section{Efikasi Diri}

Bandura mengatakan bahwa efikasi diri adalah penilaian seseorang tentang kemampuan dirinya untuk mengorganisasi dan mengerjakan tugas pembelajaran untuk mencapai sebuah keberhasilan

${ }^{7}$ Santrock, John, W. Psikologi Pendidikan : edisi Kedua, (Jakarta : Kencana, 2007).

${ }^{8}$ Hergenhann, B. R. \& Olson, M. H. An Introduction to Theories of Learning : Fofth Edition, (NJ : Prentice-Hall, 1997). 
atau prestasi tertentu. Bandura juga mengatakan bahwa efikasi diri adalah sebuah penilaian tentang satu kemampuan diri untuk menyelesaikan sebuah tugas yang ditunjukkan dengan sebuah hasil atau prestasi. ${ }^{9}$

Selanjutnya Bandura dalam Heslin dan Klehe mengatakan bahwa efikasi diri adalah kepercayaan diri seseorang terhadap kemampuan yang dimiliki untuk mencapai sebuah presatasi kesuksesan dalam mengerjakan tugas. Efikasi diri merupakan motivasi diri yang sangat kuat sebagai prediktor penting dalam seseorang melakukan sebuah tugas dengan baik ${ }^{10}$.

Bandura mengatakan bahwa efikasi diri adalah rasa percaya diri seseorang terhadap kemampuan yang dimiliki untuk memkorelasii kehidupan mereka. Rasa percaya diri berkorelasi terhadap bagaimana seseorang merasakan, berpikir, memotivasi diri, untuk menggapai sebuah kesuksesan tugas yang dikerjakan ${ }^{11}$.

Elizabeth dan Bandura mengatakan bahwa efikasi diri adalah seseorang percaya bahwa dirinya memiliki kemampuan untuk menggerakkan motivasi yang tertanam dalam diri serta efikasi juga berkorelasi terhadap memilih tindakan aktivitas yang akan dikerjakan dan juga terhadap cara seseorang memilih lingkungan untuk bergaul antar sesama baik itu teman sejawat atapun dengan orang yang lebih dewasa ${ }^{12}$.

\section{Faktor-faktor yang Mengkorelasi Efikasi Diri}

Menurut Bandura ada empat sumber yang mengkorelasikan efikasi diri yaitu: ${ }^{13}$

a. Performance Accomplishment

Ini adalah sumber informasi efikasi yang paling berkorelasi. Sebab, ini adalah sebagai pondasi seseorang untuk menguasai pengalamannya. Pencapaian prestasi adalah informasi yang secara langsung yang dapat

${ }^{9}$ Bandura, A. Social Foundation of Thought and Action A Social Cognitive Theory, (Stanford University, 1986). hlm. 391.

${ }^{10}$ Heslindan Klehe. Self Efficacy, Encyclopedia of Industrial/Organizational Psychology. Vo.2.p, (2006). hal 705-708.

${ }^{11}$ Bandura, A. Perceived Self-Efficacy In Cognitive Development And Functioning, (Stanford University: Educational Psychologist, 28 (02), 1993). hlm, 117-148.

${ }^{12}$ Elizabeth dan Bandura, Mechanisms governing empowerment effects: A selfefficacy analysis, (Journal of Personality and Social Psychology, Vol 58 (3), 1990), hlm, 472-486.

13 Bandura, A. Explorations in self-efficacy. In S. Sukemune (Ed.), Advances in social learning theory, (Tokyo: Kaneko-shoho, 1985). hlm. 195. 
menunjukkan sebuah kesuksesan. Tetapi perlu diingat bahwa pencapaian prestasi bukan berarti sama dengan efikasi diri. Memilki sebuah kemampuan untuk menanggulangi permasalahan adalah hal penting yang sangat berkonstribusi terhadap efikasi pribadi seseorang. Behavioral capabilities melalui metode juga bisa mempertinggi efikasi diri seseorang. Melalui metode juga dapat memberikan tambahan kesempatan untuk menterjemahkan konsep tindakan atau tingkah laku yang tepat, untuk membuat dan memperbaiki kehalusan budi bahasa ke arah kemampuan yang lebih sempurna. Proses kognitif, seperti (persepsi kemampuan seseorang) yang berkaitan dengan prestasi akan memkorelasii penilaian dan keyakinan efikasi diri. Bandura juga mengatakan bahwa pengalaman yang diperoleh melalui usaha yang continue dan kemampuan untuk belajar dapat membentuk efikasi diri yang kuat dan fleksibel. Namun jika efikasi diri yang didasari dari kesuksesan yang datang dengan mudah tidak akan bertahan lama ketika muncul berbagai kesulitan, dan efikasi diri tersebut akan berubah dengan cepat.

b. Vicarious experience

Manusia tidak sepenuhnya hanya bersandar pada penguasaan pengalamannya sebagai satu-satunya sumber informasi mengenai tingkat efikasi diri mereka, meskipun hal tersebut juga sangat penting dalam meningkatkan efikasi diri, namun manusia juga dapat bersandar terhadap apa yang mereka lihat yaitu melalui pemetodean, Seperti yang dinyatakan oleh Bandura " jika seseorang melihat orang lain seperti dirinya, yang berhasil karena berusaha keras, mereka yakin bahwa mereka juga punya kapasitas untuk sukses. Dan sebaliknya jika seseorang melihat orang lain gagal dan memiliki kapasitas yang sama dengan dirinya maka juga dapat menurunkan efikasi diri orang tersebut. Ketika orang melihat satu metode yang cocok pada umumnya akan sangat berefek terhadap harapan personal efficacy. Jika metode tersebut cocok maka akan mempertinggi efikasi diri dan sebaliknya jika tidak sesuai dengan apa yang diharapakan oleh individu akan menurunkan efikasi.

\section{c. Verbal Persuasion}

Mencoba untuk memkorelasii tindakan manusia, persuasi verbal seringkali digunakan, karena hal tersebut merupakan hal yang mudah untuk dilakukan baik untuk menyemangati seseorang atapun sebaliknya. Dengan seseorang berkata "you can do it" terhadap orang lain, ini adalah persuasi verbal yang dapat memotivasi seseorang dan dapat menambah efikasi diri dan sebaliknya jika seseorang berkata "you can't do it" terhadap orang lain ini akan menyebabkan orang menjadi ragu untuk melakukan tugas atau pekerjaannya sekaligus akan menurunkan efikasi

$120 \mid$ JURNAL LISAN AL-HAL 
diri seseorang. Persuasi verbal yang positif dapat menenangkan seseorang dan sebaliknya persuasi verbal negatif dapat membuat orang bingung atau ragu untuk melakukan suatu tugas.

Dengan persuasi verbal seseorang akan lebih memiliki kemampuan untuk siap melakukan suatu pekerjaan atau tugas dan akan memiliki kemampuan untuk menguasai situasi yang sulit. Meskipun persuasi verbal adalah bantuan yang sifatnya sementara untuk efektifnya sebuah tindakan, namun hal tersebut sangat berkonstribusi untuk sebuah kesuksesan seseorang karena dengan persuai verbal seseroang dapat termotivasi ataupun sebaliknya.

d. Emosional Arousal

Situasi yang penuh dengan tekanan, pikiran penuh dengan beban dan keadaan fisik yang kurang sehat biasanya akan mendatangkan emosi yang kurang baik misalnya, (orang yang sangat lelah, tidak sehat secara fisik, cemas dan merasa tertekan), maka hal tersebut akan sangat menurunkan efikasi. Hal tersebut mungnkin akan menjadi sumber hasil infomasi mengenai personal competence. Keadaan emosi yang tidak stabil biasanya akan mengurangi performance dan kemungkin besar individu akan sukses ketika mereka tidak ditimpa oleh keengganan dan kecemasan, sebab jika mereka merasa tegang dan merasa gelisah secara mendalam akan menurunkan efikasi. Kesimpulannya, jika individu berada dalam kondisi mental dan fisik yang sehat, maka hal tersebut merupakan awal yang baik untuk membangun efikasi. Kondisi tersebut juga meningkatkan efikasi seseorang pada tugas yang menuntut kondisi fisik dan psikologis yang baik.

\section{Srategi untuk Meningkatkan Efikasi diri Siswa (Stipek dalam} Santrock) ${ }^{14}$.

a. Teach specific strategies. Mengajar siswa dengan spesifik strategi, seperti mengajarkan bagaimana menguraikan dan meringkas dengan mengajarkan siswa cara mengurai dan meringkas dapat meningkatkan kemampuan mereka untuk fokus pada tugas-tugas.

b. Guide students in setting goals. Membantu siswa untuk membuat tujuan jangka pendek setelah mereka membuat tujuan jangka panjang. Tujuan jangka pendek dapat membantu siswa untuk menilai kemajuan atau perkembangan efikasi diri mereka dalam belajar.

14 Santrock, J W. Life-Span Development: Perkembangan Masa Hidup, (Jakarta: Erlangga, 2008), hlm. 463. 
c. Consider mastery. Berikan siswa "performance-contingent reward "siswa diberikan hadiah dengan sebuah syarat, hadiah tersebut sebagai signal atau tanda yang mungkin dapat membantu siswa dalam pengusaan materi pelajaran. Dari pada hanya diberikan sebuah hadiah karena mengerjakan sebuah tugas.

d. Combine strategies training with goal. Schunk dkk, dalam Santrock ${ }^{15}$ telah menemukan sebuah kombinasi pelatihan strategi dan penentuan tujuan dapat mempertinggi efikasi diri siswa dan dapat mengembangkan skill/keahlian siswa. Berikan penjelasan kepada siswa bahwa strategi belajar mereka berhubungan dengan prestasi belajar.

e. Provide students with support. Positive support bisa dari guru, orang tua, dan teman sejawat. Kadang-kadang seorang guru hanya butuh mengatakan kepada siswa "you can do this (kamu pasti bisa melakukan ini) ". Orang tua untuk memotivasi anaknya ialah dengan memberikan dukungan, masukan disaat melihat anak mulai malas belajar dan teman sejawat ialah dengan meberikan motivasi dan saling membantu apabila ada kesulitan dalam belajar.

f. Make sure that students are not overly aroused and anxious. Buat siswa yakin bahwa mereka tidak perlu bingung dan khawatir, karena ketika siswa sangat khawatir dan merasa takut tentang prestasi mereka, efikasi diri siswa akan menurun.

g. Provide students with positive adult and peer metode.Karakteristik metode dapat membantu mengembangkan efikasi diri siswa. Seperti contoh, siswa yang melihat dan mengamati guru dan teman sejawatnya dalam mengatasi dan menguasai tantangan secara efektif seringkali akan mengadopsi perilaku dari guru dan temannya. Metodeing amat efektif dalam meningkatkan efikasi diri apabila siswa melihat teman yang sukses adalah teman yang kemampuannya sama dengan dirinya.

\section{Hasil Uji Efikasi Diri}

Berdasarkan hasil analisa ternyata nilai $r x y=0,394$ angka ini lebih besar dari taraf signifikan $5 \%=0,334$ dengan $\mathrm{N}=35$. Berarti signifikan sehingga hipotesa nihil yang berbunyi " Tidak ada korelasi Pendekatan Behavior Dengan Efikasi Diri Siswa “ ( ditolak ).

Hipotesa kerja mayor yang berbunyi ada korelasi Pendekatan Behavior Dengan Efikasi Diri Siswa ( diterima ). Dan Hipotesa kerja minor

${ }^{15}$ Santrock, J. W. Educational psychology, (3 ${ }^{\text {th }}$ ed), (New York: McGraw Hill, 2008).

122 JURNAL LISAN AL-HAL 
yang berbunyi ada korelasi Pendekatan Behavior Operant Conditioning Dengan Efikasi Diri Siswa ( diterima ). Berarti ada korelasi Pendekatan Behavior Operant Conditioning Dengan Efikasi Diri Siswa ( diterima), selanjutnya untuk mengetahui seberapa jauh korelasinya, penulis korelasikan dengan product moment diperoleh hasil 0,394 sedangkan hasil ini lebih besar dari $r$ table.

Kemudian dalam menginterpretasikan korelasi hasil analisa data akan disesuaikan dengan kriteria sebagai berikut :

$r x y=\ldots \ldots . . . .<0.20$ Hubungan sangat kecil

$0.20-0.40$ Korelasi rendah

$0.40-0.70$ Korelasi sedang

$0.70-0.90$ Korelasi tinggi

0.90 - 1.00 Korelasi sangat tinggi

Dari hasil analisa nilai rxy $=0,394$, sehingga termasuk dalam kategori hubungan rendah $(0,20-0,40)$.

\section{Simpulan}

Berdasarkan hasil penelitian maka dapat disimpulkan bahwa ada korelasi pendekatan behavior terhadap efikasi diri siswa hal ini ditunjukkan dengan adanya hasil analisa nilai rxy $=0,394$ angka ini lebih besar dari taraf signifikan $5 \%=0,334$ dengan $\mathrm{N}=35$. Berarti signifikan sehingga hipotesa nihil yang berbunyi " Tidak ada korelasi Pendekatan Behavior Dengan Efikasi Diri Siswa " (ditolak). Berarti ada korelasi Pendekatan Behavior Operant Conditioning Dengan Efikasi Diri Siswa.

\section{DAFTAR PUSTAKA}

Arikunto, Suharsimi, Ilmu Pendidikan Dalam Perspektif Islam. PT Remaja Rosdakarya: Bandung, 2002.

Bandura, A. Explorations in self-efficacy. In S. Sukemune (Ed.), Advances in social learning theory. Tokyo: Kaneko-shoho, 1985.

Bandura, A. Perceived Self-Efficacy In Cognitive Development And Functioning. Stanford University: Educational Psychologist, 28 (02),1993.

Bandura, A. Social Foundation of Thought and Action A Social Cognitive Theory. Stanford University, 1986.

Elizabeth dan Bandura, Mechanisms governing empowerment effects: A selfefficacy analysis. Journal of Personality and Social Psychology, Vol 58(3), 1990. 
Hergenhann, B. R. \& Olson, M. H, An Introduction to Theories of Learning : Fofth Edition. NJ : Prentice-Hall, 1997.

Heslindan Klehe, Self Efficacy, Encyclopedia Of Industrial/Organizational Psychology. Vo.2.p. hal 705-708, 2006

Kartika N., F. \& Farida H. Konseling Sebaya untuk Meningkatan Efikasi Diri Remaja terhadap Perilaku Berisiko. UNY, 2008.

Kompas, Senin, 18 Agustus, 2008.

Metrotvnews.com)17 April, 2012.

Santrock, J W. Life-Span Development: Perkembangan Masa Hidup. Jakarta: Erlangga, 2008.

Santrock, J. W. Educational psychology, (3 ${ }^{\text {th }}$ ed). New York: McGraw Hill, 2008.

Santrock, John, W. Psikologi Pendidikan. edisi Kedua. Jakarta: Kencana, 2007.

Undang -Undang RI No.20, Sistem Pendidikan Nasional Bab II Pasal 3. 2003.

WWW.misscounseling.blogspot.com). 